RESEARCH ARTICLE

\title{
FUNCTIONAL CONSTITUENTS OF FRUIT JUICES AFTER ACETIC ACID FERMENTATION
}

\author{
Amal Buddhika, Buddhika Niroshie Perumpuli*, Nirosha Dilrukshi \\ Department of Food Science and Technology, Faculty of Agriculture, University of Ruhuna, \\ Mapalana, Kamburupitya, Sri Lanka
}

Received: 12 August 2021: Accepted: 02 December 2021

\begin{abstract}
Fruits are dense sources of nutrients with many functional properties. Acetification of fruit juices generates different types of fruit vinegar with a variety of flavors and uses. In this study, Alcoholic juices fermented by employing Saccharomyces cerevisiae were subjected to acetification by pre-cultured Acetobacter pasteurianus PP21 at both $30^{\circ} \mathrm{C}$ and $36^{\circ} \mathrm{C}$ temperatures and they were tested for their Brix value, titratable acidity, alcohol content, antioxidant activity, phenolic content and flavonoid contents. Compared to the acetic acid production at $36{ }^{\circ} \mathrm{C}$, both mango and jackfruit juices showed their peak acetic acid production of $4.5 \pm 0.015 \%(w / v)$ and $4.2 \pm 0.04 \%$ (w/v) respectively, at $30{ }^{\circ} \mathrm{C}$. The final Brix value of mango and jackfruit juices subjected to acetification at $30{ }^{\circ} \mathrm{C}$ and $36^{\circ} \mathrm{C}$ was found to be constant at 3.6, 5.7, and 3.1, 5.7 ${ }^{\circ} \mathrm{Bx}$ respectively. Furthermore, the final alcohol level of all the vinegar samples was found to be less than $0.5 \%(\mathrm{v} / \mathrm{v})$. Moreover, the antioxidant activity, phenolic content and flavonoid contents of both mango and jackfruit juices after acetification were significantly higher $(p<0.05)$ at $36{ }^{\circ} \mathrm{C}$ compared to vinegar produced at $30{ }^{\circ} \mathrm{C}$. As per the results, both mango and jackfruit juices can be successfully used as a potential source of functional constituents in vinegar production at both $30^{\circ} \mathrm{C}$ and $36^{\circ} \mathrm{C}$.
\end{abstract}

Keywords: Acetic acid bacteria, Bioactivity, Fermentation, Fruit vinegar, Jackfruit, Mango

\section{INTRODUCTION}

Mango (Mangifera indica) and Jackfruit (Artocarpus heterophyllus) are popular tropical fruits having higher nutritional significance, a delicious taste and aroma, and benefits to human health (Masibo and He, 2008). Major carbohydrates found in ripen mango flesh are sucrose, glucose and fructose (Quintana et al. 2021; Torres-León, 2016). Additionally, it contains dietary fiber such as cellulose, hemicellulose and lignin, and pectin in smaller amounts (Bello-Pérez et al. 2007). Functional constituents of mango flesh include phenolic acids such as gallic, vanillic, syringic, protocatechuic like hydroxybenzoic acid derivatives, and p-coumaric, chlorogenic, ferulic, and caffeic acids like hydroxycinnamic acid derivatives (Burton-Freeman et al. 2017); Flavonoids and other polyphenolic compounds such as catechins, kaempferol, anthocyanins, and tannic acid (Haytowitz et al. 2018;

Corresponding author: buddhikap@fst.ruh.ac.lk
Ediriweera et al. 2017); and pigments such as chlorophylls, carotenoids, and flavonoids (Nelson and Cox, 2017; Choo, 2018; Ellong et al. 2015). The variety of mango and their ripening stage plays an important role in the amounts of carbohydrates present in the flesh, for the generation of aroma compounds and the ethylene production (Maldonado-Celis et al. 2019).

The nutritional and functional significance of jackfruit flesh is associated with the carbohydrates, proteins, lipids, vitamins and minerals, and the phytochemicals present in it. The fruit contains starch and dietary fiber which are increased with the fruit maturity (Ranasinghe et al. 2019). It is a rich source of many phytochemicals including phenolic compounds, carotenoids, flavonoids, volatile acids, sterols, and tannins (Chandrika et al. 2004; Amadi et al. 2018). Different types of carotene present include $\beta$-carotene, $\alpha$ - 
carotene, $\beta$-zeacarotene, $\alpha$-zeacarotene and $\beta$ carotene-5,6 $\alpha$-epoxide and a dicarboxylic carotenoid and crocetin (Chandrika et al. 2004).

Fermentation of alcoholic juices of fruits into fruit vinegar like products have become prominent worldwide. Different types of fruit vinegar are being produced with the variety of raw materials. Acetification of fruit juices enables the retention of functional characteristics of the raw materials compared to other processing techniques applied on fruit product development and also can be used as a way of treating excessive fruit surplus. Acetobacter and Gluconacetobacter are the most popular genera of Acetic acid bacteria (AAB) used in vinegar fermentation. They have been identified as powerful in oxidizing ethanol and in tolerating the accumulated acetic acid concentration in the medium (Lynch et al. 2019). Usually, the industrial acetic fermentation is performed around $30{ }^{\circ} \mathrm{C}$ using mesophilic strains that are capable of growing and performing oxidative fermentation better at this temperature. Increasing atmospheric temperatures have possess some practical problems to the fermentation industries, as they require huge cooling systems to maintain the fermentation temperatures for the optimum functioning of acetic acid bacteria. Instead, recent studies have identified the potential of some acetic acid bacterial strains to perform acetic acid production at higher temperatures.

There are many studies conducted on the development and compositional analysis related to various fruit vinegar (cider vinegar, grape vinegar, strawberry vinegar) based on the acetic acid fermentation (Yunyang 2005; Budak et al. 2015; Pure and Pure 2016). However, the presence of the functional constituents of mango and jackfruit juice after fermentation are limited in the previous literature. Therefore, this study identifies the functional constituents present in mango and jackfruit juice after subjecting to alcoholic and acetic acid fermentation using Acetobacter pasteurianus $\mathrm{PP} 21$ at both $30^{\circ} \mathrm{C}$ and $36^{\circ} \mathrm{C}$.

\section{MATERIAL AND METHODS \\ Substrates}

Fresh quality, fully ripen (ripen stage 04) mangoes of siini amba variety and fully ripen jackfruit were collected from the local market, Matara, Sri Lanka. All fruits were peeled, cleaned well with tap water, and cut into small pieces. Then they were blended with water (1:1 ratio) until a homogenous mixture was obtained. Unwanted particles were removed by filtering the blended juice using a clean cheesecloth and centrifuging the filtrate at 5,500 rpm for $7 \mathrm{~min}$. The initial Brix value of both mango and jackfruit juice was adjusted to $12^{\circ} \mathrm{Bx}$ by adding table sugar.

\section{Preparation of the inoculum}

Both yeast and $\mathrm{AAB}$ inoculums were prepared according to a procedure described by Konate et al. (2015) with some modifications. For the preparation of yeast inoculum, $0.5 \mathrm{~g}$ of yeast powder was added to a $100 \mathrm{~mL}$ of $10 \%$ sucrose $(\mathrm{w} / \mathrm{v})$ solution, incubated for one hour at $30{ }^{\circ} \mathrm{C}$, and $20 \mathrm{~mL}$ of the yeast inoculum was added to inoculate one liter of fruit juice. Acetobacter pasteurianus PP21 was pre-cultured in YPGD medium (0.5 $\mathrm{g}$ of yeast extract, $0.5 \mathrm{~g}$ of polypeptone, $0.5 \mathrm{~g}$ of glycerol, and $0.5 \mathrm{~g}$ of glucose per $100 \mathrm{~mL}$ tap water) at $30{ }^{\circ} \mathrm{C}$ for $72 \mathrm{hrs}$, and $50 \mathrm{~mL}$ of the culture was used to inoculate one liter of the alcoholic juice.

\section{Alcoholic and acetous fermentation}

Fruit juices were separately inoculated with revitalized yeast and allowed to ferment for 72 hrs (Konate et al. 2015) at room temperature in a $2 \mathrm{~L}$ conical flask under static conditions. Afterwards, $200 \mathrm{~mL}$ of alcoholic juices; mango $\left(4.9^{\circ} \mathrm{Bx}\right)$, and jackfruit $\left(5.7^{\circ}\right.$ $\mathrm{Bx})$ was transferred into a $500 \mathrm{~mL}$ Erlenmeyer flask, and $10 \mathrm{~mL}$ of pre-cultured $\mathrm{AAB}$ inoculum was added. Flasks were sealed with a cotton plug to prevent any contaminations. At both $30{ }^{\circ} \mathrm{C}$ and $36{ }^{\circ} \mathrm{C}$ fermentation was carried out to identify the optimum temperature conditions to produce mango and jackfruit vinegar. Total sugar content, Brix value, and titratable acidity of each sample were measured daily during fermentation. 
After reaching the expected acidity level (around $4.0 \% \mathrm{w} / \mathrm{v}$ ) the obtained vinegar samples were centrifuged at 5,500 rpm for 10 min to remove all the residues and yeast cell mass. Finally, the acetification process was stopped by pasteurizing the harvested vinegar samples in a shaking water bath at $72{ }^{\circ} \mathrm{C}$ for $20 \mathrm{~min}$.

\section{Analysis of vinegar samples \\ Brix value, titratable acidity, and Alcohol content}

The Brix value of each sample was measured using a digital pocket refractometer (Atago, PAL-22S, Japan). As described by Chun et al. (2014) acid-base titration method was used to measure the Acetic acid concentration, by titrating with $0.1 \mathrm{~N} \quad \mathrm{NaOH}$ using phenolphthalein as the indicator and the total acidity was expressed as the amount of acetic acid present. The alcohol content of the samples was measured using an alcohol hydrometer (Fisherbrand, 11-590, US). All the analysis was done in triplicates.

\section{Determination of antioxidant capacity}

The method given by Brand-Williams et al. (1995) was used to identify the antioxidant activity of vinegar samples using DPPH assay, with few modifications. Initially, the samples were serially diluted with methanol to obtain $5,10,15,20 \mathrm{mg} / \mathrm{mL}$ dilution solutions. Two hundred fifty microliters of sample or control (methanol) were added to $2.75 \mathrm{~mL}$ of $50 \mu \mathrm{mol} \mathrm{DPPH}$ solution $(1.97 \mathrm{mg}$ in $100 \mathrm{~mL}$ of methanol) separately, and the absorbance at the steady-state was measured with UV visible spectrophotometer $(\mathrm{HACH}$, DR3900, Germany) at $517 \mathrm{~nm}$. The inhibition percentage of the samples was calculated according to equation 01 , and the inhibition percentage was plotted against sample concentration. The amount of sample required to inhibit $50 \%$ of the initial DPPH (EC50 value) was calculated from a calibration curve determined by linear regression.

\section{Percentage inhibition $=$}

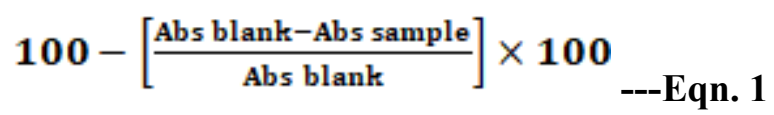

\section{Determination of total phenolic content}

Folin-Ciocalteu reagent was used to determine the total phenol content of samples using the methodology given by Singleton et al. (1999) with some modifications. Two milliliters of Folin-Ciocalteu reagent which has been diluted previously with 10 -fold distilled water was mixed with an accurately diluted $400 \mu \mathrm{L}$ of the sample. After one minute and within eight minutes period, $2 \mathrm{~mL}$ of $7.5 \%$ sodium bicarbonate solution was added to stop the reaction, and then volumed up to $10 \mathrm{~mL}$ using distilled water. This mixture was placed at dark for 120 minutes, and the absorbance was measured at $760 \mathrm{~nm}$. Results were expressed as $\mathrm{mg}$ of gallic acid equivalents per liter ( $\mathrm{mg}$ GAE/l) using the equation obtained by linear regression of gallic acid standard curve prepared by serially diluted gallic acid solution $(250,125,62.5,31.25,15.625,7.812$, 3.906, $1.953 \mu \mathrm{g} / \mathrm{mL})$

\section{Determination of total flavonoid content}

A colorimetric assay was used to determine the total flavonoid content according to a method described by Zhishen et al. (1999). One mililiter from properly diluted aqueous or methanolic fractions of the samples or catechin standard solutions or (water or methanol) the blank solution was added to 10 $\mathrm{mL}$ volumetric flask, and $4 \mathrm{~mL}$ of distilled water was added. At the beginning, $0.3 \mathrm{~mL}$ of $5 \% \mathrm{NaNO}_{2}$ was added, and 5 min later, 0.3 $\mathrm{mL}$ of $10 \% \mathrm{AlCl}_{3}$ was added to the mixture. At the $6^{\text {th }}$ min, $2 \mathrm{~mL}$ of $1 \mathrm{M} \mathrm{NaOH}$ was added, and the solution was volumed up to $10 \mathrm{~mL}$ with distilled water and the mixture was mixed well. After $15 \mathrm{~min}$ period, the absorbance was determined at $510 \mathrm{~nm}$. The total flavonoid content was expressed as milligrams of catechin equivalent per $100 \mathrm{~mL}$ of the sample by equation obtained by linear regression of catechin standard curve prepared by serially diluted catechin solution $(250,125$, $62.5,31.25 \mu \mathrm{g} / \mathrm{mL}$ ).

\section{RESULTS AND DISCUSSION Production of mango and jackfruit vinegar at $30{ }^{\circ} \mathrm{C}$ and $36^{\circ} \mathrm{C}$}

Changes in the chemical composition of the developed mango and jackfruit vinegar were measured in terms of Brix value, alcohol 
content, and titratable acidity at $30{ }^{\circ} \mathrm{C}$ and 36 ${ }^{\circ} \mathrm{C}$, and the results are summarized in fig. 01 . Simultaneous vinegar production consists of two sequential fermentation steps where the initial alcoholic fermentation happens with the yeast action, and subsequently, the acetification occurs by the action of AAB. As per the results in Fig. 1, initially, the ethanol production has occurred, and both mango and jackfruit wines gave more than $4 \%(\mathrm{v} / \mathrm{v})$ alcohol production at both tested temperatures. However, the highest alcohol production was observed in mango wine produced at $30{ }^{\circ} \mathrm{C}$, and it was significantly higher $(p<0.05)$ than the other wine types produced. Furthermore, both mango and jackfruit wines gave a comparatively higher amount of alcohol production at $30^{\circ} \mathrm{C}$. This is mainly due to the favorable temperature conditions for the fermentation of Saccharomyces cerevisiae at $30{ }^{\circ} \mathrm{C}$. According to a study by Li et al. (2012), the ethanol content of three different mango wines produced from three types of mango juice (where initial Brix varied between 13.25 \pm 0.00 to $16.82 \pm 0.00{ }^{\circ} \mathrm{Bx}$ ) was found to be ranged from $6.33 \pm 0.96$ to $8.05 \pm 1.15 \%(\mathrm{v} /$ v). Accordingly, in the current study, a similar pattern of alcohol production by $S$. cerevisiae was observed at both tested temperature levels. Expected alcohol level when a traditional substrate is being used in the production process is therefore deviated to a higher magnitude in case of fruit vinegar production.

Brix value represents the level of soluble solids present in a solution. Fruit juices primarily contain sugars as their soluble solids and thus, the Brix value shows the estimates of sugar in a particular fruit juice sample. As it is shown in Fig. 1, with the progression of the alcohol production, Brix value of all the vinegar samples was started to decline. Reduction of the Brix value with the fermentation time indicates that more sugar is being utilized by yeast to convert them into alcohols (Saha and Banerjee 2013). However, the available sugar samples in all four vinegar samples were not completely oxidized, and thus the Brix value was found to remain constant after the peak alcohol production of mango and jackfruit vinegar produced either at $30{ }^{\circ} \mathrm{C}$ or $36^{\circ} \mathrm{C}$, thus giving a sweet taste to the final product. As it is shown in Fig. 1, the Brix value of mango and jackfruit vinegar produced at $30{ }^{\circ} \mathrm{C}$ was found to remain as 3.6 ${ }^{\circ} \mathrm{Bx}$ and $5.7{ }^{\circ} \mathrm{Bx}$ respectively. Furthermore, that of mango and jackfruit vinegar samples produced at $36{ }^{\circ} \mathrm{C}$ was also found to be constant at $3.1^{\circ} \mathrm{Bx}$ and $5.7^{\circ} \mathrm{Bx}$ respectively. Additionally, the Chinese National Standard (2005) stated that fruit vinegar should contain not less than $1.2 \%$ salt-excluded soluble solids, and as per the results shown in Fig.1, the remaining total soluble solids of all the vinegar samples were found to be within the standard level. Thus, the results highlighted that a higher amount of sugar is converted efficiently into alcohol in mango juice fermentation compared to jackfruit juice. Moreover, according to Kim et al. (2012), the readily available sugar in fruit vinegar is glucose while fructose, sucrose, maltose, and other sugars affecting the sweetness exist in smaller quantities.

Conferring to the results, the total titratable acidity of the alcoholic juice of mango and jackfruit at the time of acetic acid bacteria inoculation was found to be $0.51 \mathrm{~g} / \mathrm{L}$ and 0.86 $\mathrm{g} / \mathrm{L}$ respectively. During the progression of fermentation at $30{ }^{\circ} \mathrm{C}$, the mango juice showed its peak acetic acid production of 4.5 $\pm 0.015 \%(\mathrm{w} / \mathrm{v})$ on the $7^{\text {th }}$ day of the fermentation. Comparatively, at the same temperature level, the peak acetic acid production in jackfruit vinegar $(4.2 \pm 0.04 \%$ $(\mathrm{w} / \mathrm{v}))$ was observed on the $6^{\text {th }}$ day of the fermentation cycle. The increase in the acetic acid level in all four vinegar types is due to the oxidation of available ethanol by $\mathrm{AAB}$ under aerobic conditions. Thus, ethanol has become the main source of carbon for $\mathrm{AAB}$, and this leads to a drastic reduction in ethanol level in the vinegar media with the progression of acetic acid fermentation (Fig.1). However, as per the results shown in Fig. 1, the residual alcohol level of all four vinegar types was found to be less than $0.5 \%$ (Joint FAO/WHO Food Standards Programme 2000). 
Furthermore, the increase in titratable acidity during the acetification is mainly due to the accumulation of organic acids, particularly acetic acid produced by the AAB. However, according to Chidi et al. (2015), a small amount of acetic acid could be produced by yeast as a by-product of alcoholic fermentation. Nevertheless, with the continuation of the fermentation process, a reduction of the acetic acid level was found especially at $30{ }^{\circ} \mathrm{C}$ which is due to the overoxidation of the produced acetic acid (Gullo et al. 2006). In contrast, compared to the acetic acid production at $30{ }^{\circ} \mathrm{C}$, both mango and jackfruit vinegar showed significantly low $(p<0.05)$ amount of acetic acid production at $36{ }^{\circ} \mathrm{C}$, and it was ranged between $3.65 \pm 0.162$ to $3.74 \pm 0.00 \%$ (w/v). Moreover, according to a study done by Bouatenin (2021), the titratable acidity of mango and papaya vinegar was reported as $6.12 \pm 0.14 \%$ and $5.88 \pm 0.42 \%(\mathrm{w} / \mathrm{v})$. According to the Chinese National Standard (2005), the acidity level of fruit vinegar should be not less than $4.5 \%$ (calculated as acetic acid). However, as per the obtained results, only the mango vinegar produced at $30{ }^{\circ} \mathrm{C}$ could be able to reach the standard level of acetic acid.

\section{Bioactivity of the developed vinegar samples}

Total phenolic content, flavonoid content, and the antioxidant activity of both mango and jackfruit vinegar produced at $30{ }^{\circ} \mathrm{C}$ and $36{ }^{\circ} \mathrm{C}$ are summarized in Table 1.

\section{Total phenolic content}

As per the results shown in Table 1, compared to the vinegar produced at $30{ }^{\circ} \mathrm{C}$, and $36{ }^{\circ} \mathrm{C}$, the unfermented fruit juice of mango and jackfruit are having a significantly $(p<0.05)$ higher level of total phenols. Moreover, the total phenol content of unfermented mango juice $(1590.826 \pm 11.161$ $\mathrm{mg}$ GAE/L) was found to be three times greater than that of unfermented jackfruit juice $(590.645 \pm 16.623 \mathrm{mg}$ GAE/L). Furthermore, the phenol content of mango was regarded as high when compared with other phenol rich fruits such as pomegranate (1387 mg GAE/L) (Ordoudi et al. 2014) and blueberries $(86.7 \pm 1.56 \mathrm{mg}$ GAE/100 mL) (Su and Chien 2007) that have been utilized as raw materials in the production process of vinegar. However, in the current study, the total phenolic content was found to be significantly less than their unfermented fruit juices where a five times reduction is being observed in mango vinegar and the reduction in jackfruit vinegar was only two times.

There are many types of research done on the phenolic content of alcoholic fermentation. However, little is known about the variation in phenolic content in the acetification process. According to the study by $\mathrm{Su}$ and Chien (2007) the total phenolic content of the blueberry vinegar $(98.1 \pm 1.66 \mathrm{mg} \mathrm{GAE} / 100$ $\mathrm{mL}$ ) was found to be significantly higher than that of blueberry juice and blueberry wine $(86.7 \pm 1.56$ and $85.8 \pm 1.54 \mathrm{mg} \mathrm{GAE} / 100 \mathrm{~mL}$ respectively). Furthermore, a study done by Ubeda et al. (2013) has shown that the type of container used in the acetification process affects the total phenolic content produced during acetification. According to them, the use of glass vessels reported the lowest values for total phenolic content, and the use of wooden barrels has increased the tested parameters. Moreover, they have found that the vinegar produced using cherry barrels showing a higher antioxidant activity while the vinegar produced by oak barrels showing a higher total phenol content. According to them, the difference in the bioactivity is mainly due to the difference in porosity wood that facilitates the oxygen permeation. However, in the current study, acetification of fruit vinegar was done using glass vessels, and thus, as reported by Ubeda et al. (2013), the acetic acid production will be badly affected by the less porous nature in glass vessels, and concurrently a reduction in phenol content during acetous fermentation was observed. Moreover, according to Ubeda et al. (2013), centrifugation and pasteurization of vinegar samples will also reduce the antioxidant compounds, and thus, the reduction in total phenolic content in the current study could be also due to centrifugation and pasteurization of the produced vinegar samples. 
(a)

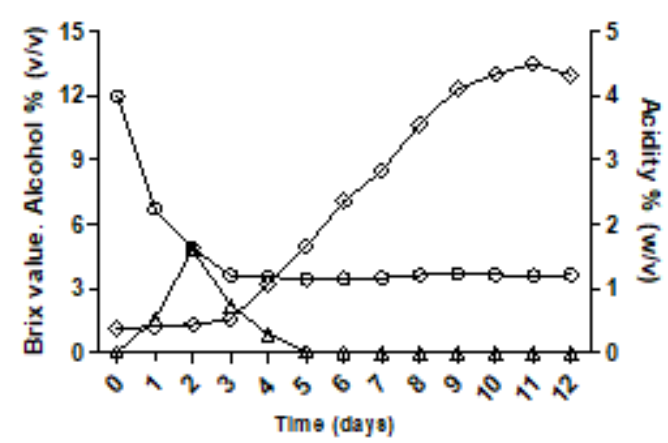

(b)

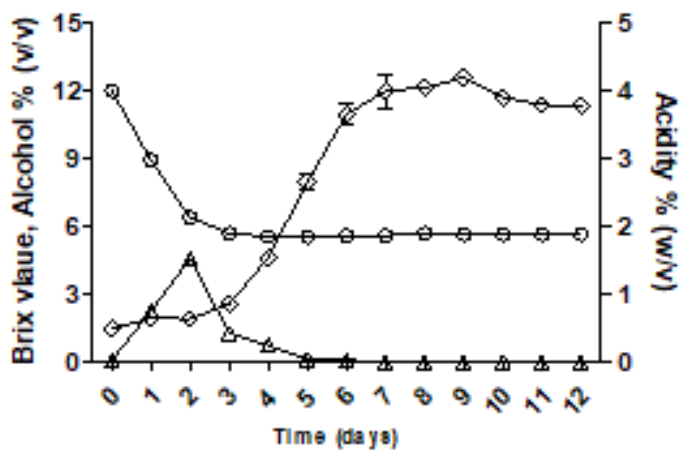

$36^{\circ} \mathrm{C}$
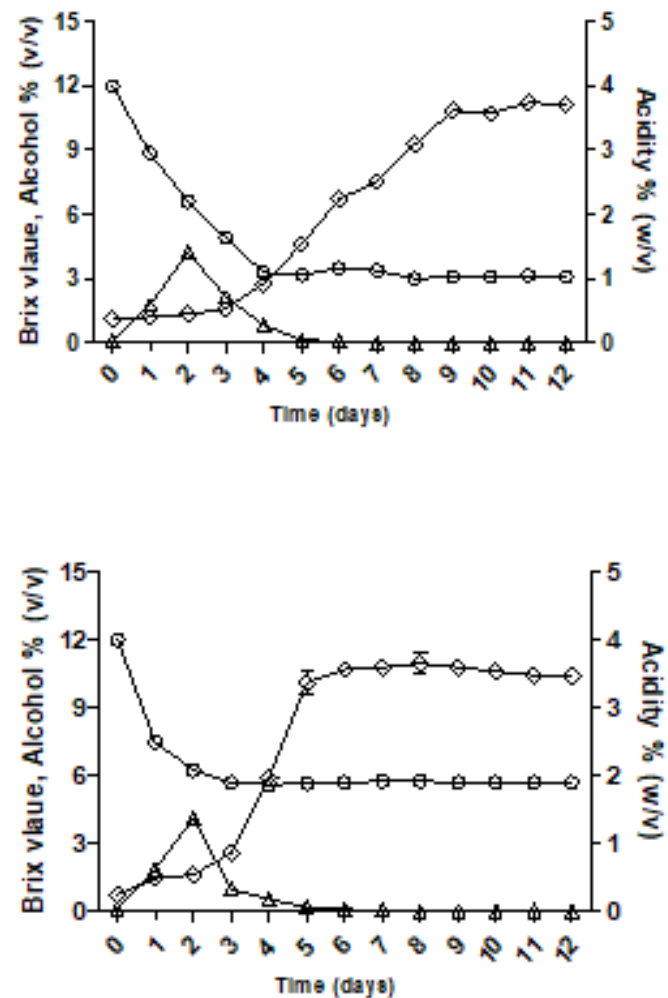

Figure 1: Changes of Brix value (circle), alcohol (triangle) content, and titratable acidity (square) during alcoholic and acetous fermentation of mango (a) jackfruit (b) at $30^{\circ} \mathrm{C}$, and $36^{\circ} \mathrm{C}$

As per the results of the current study (Table 1), mango vinegar produced at $36{ }^{\circ} \mathrm{C}$ is having a significantly higher $(\mathrm{p}<0.05)$ level of total phenols compared to the production at $30{ }^{\circ} \mathrm{C}$. Moreover, when considering the jackfruit vinegar, when compared to the total phenol content at $36{ }^{\circ} \mathrm{C}$, a significantly higher level of total phenols content was observed at $30{ }^{\circ} \mathrm{C}(333.869 \pm 19.657 \mathrm{mg}$ GAE/L). Higher total phenol content is an indication of wellfermented vinegar (García-Parrilla, 1997) and thus, effective vinegar fermentation with desirable phenolic content could be reached at $36{ }^{\circ} \mathrm{C}$ for mango vinegar and $30^{\circ} \mathrm{C}$ for jackfruit vinegar.

\section{Total antioxidant activity}

DPPH radical scavenging activity is measured as the inhibition percentage of the free radicals by antioxidants, and thus, the EC50 value indicates the concentration required to have a $50 \%$ antioxidant effect (Chen et al.
2013) was calculated. The obtained results are summarized in Table 01. As per the results, compared to the vinegar samples, the unfermented mango juice and jackfruit juice showed a higher DPPH radical scavenging activity. Moreover, the DPPH radical scavenging activity (EC50 value of 2.24) was highest in unfermented mango juice. Furthermore, the results demonstrate that the antioxidant activity of all four types of vinegar is being significantly reduced with the fermentation process. Larrauri et al., (1996) has stated that the antioxidant activity is depending on the structural constitution of the phenolic compounds available. As it is clearly shown in Table 1, the total phenol content of all the vinegar samples was found to be significantly reduced with the acetification process. Thus, the reduction in total phenol content during acetic acid fermentation has led to the reduction in the radical scavenging activity of the produced vinegar. However, in 
Table 1: Antioxidant activity, total phenolic content, total flavonoid content of Mango and Jackfruit; raw juice, vinegar at $30^{\circ} \mathrm{C}$ and $36^{\circ} \mathrm{C}$

\begin{tabular}{|c|c|c|c|c|}
\hline & & $\mathbf{E C}_{50}$ & $\begin{array}{c}\text { Total phenols mg } \\
\text { GAE/L }\end{array}$ & $\begin{array}{c}\text { Total FC mg } \\
\text { CE/100 mL of } \\
\text { sample }\end{array}$ \\
\hline \multirow[t]{3}{*}{ Mango } & Raw juice & $2.24^{\mathrm{C}}$ & $1590.826^{\mathrm{a}} \pm 11.161$ & $46.210^{\mathrm{a}} \pm 3.481$ \\
\hline & Vinegar at $30^{\circ} \mathrm{C}$ & $10.96^{\mathrm{b}}$ & $340.826^{c} \pm 6.907$ & $19.515^{\mathrm{c}} \pm 6.577$ \\
\hline & Vinegar at $36^{\circ} \mathrm{C}$ & $11.73^{\mathrm{a}}$ & $362.997^{b} \pm 7.807$ & $20.727^{b} \pm 2.362$ \\
\hline \multirow[t]{3}{*}{ Jackfruit } & Raw juice & $3.09^{\mathrm{c}}$ & $590.645^{\mathrm{a}} \pm 16.623$ & $48.879^{\mathrm{a}} \pm 4.001$ \\
\hline & Vinegar at $30^{\circ} \mathrm{C}$ & $18.02^{\mathrm{a}}$ & $333.869^{b} \pm 19.657$ & $14.818^{c} \pm 2.405$ \\
\hline & Vinegar at $36^{\circ} \mathrm{C}$ & $15.97^{\mathrm{b}}$ & $314.602^{c} \pm 32.071$ & $19.818^{b} \pm 3.721$ \\
\hline
\end{tabular}

Data values are represented as mean \pm SE. Different lowercase letters under the same column under each vinegar type indicate a statistically significant difference $(p<0.05)$.

contrast, a study by Su and Chien (2007) has reported that the antioxidant and/or antiradical activity of a substance will be enhancing during acetification through the production of phenolic dimers and oligomers through oxidative phenolic reactions. Conversely, a study by Ordoudi et al. (2014) on pomegranate juice on alcoholic and acetic acid production, and found that the DPPH radical scavenging activity of pomegranate vinegar was $55 \%$ lower than the fresh juice. They further describe that strong radical scavengers could be partially degraded during both alcoholic and acetic acid fermentation processes. However, during the current study, such oxidative reactions could be affected due to the use of glass vessels that determines the aeration condition, where eventually a reduction in antioxidant activity is been occurred.

\section{Total flavonoid content}

The total flavonoid content of the unfermented mango and jackfruit juice and the vinegar produced at the tested temperature levels were also found to be behaving in a similar profile to the total phenolic content and the DPPH radical scavenging activity. According to the findings of Bakir et al. (2016), the total flavonoid content of both grape vinegar and apple vinegar was found to be decreased with the acetification, and the results of the current study are in accordance with it. Further, a study by Wu et al. (2017) on vinegar production using sweet potato, also showed that the total phenolic content, total flavonoid content, and DPPH radical scavenging activities were reducing over the progression of fermentation. They further describe that the difference in DPPH radical scavenging activity may be due to the production of acetic acid during acetification, as well as the antioxidants activity found in acetic acid itself.

\section{CONCLUSION}

The results of the study highlights that the possibility of mango and jackfruit juices as ideal substrates to perform acetic acid fermentation with sufficient composition of functional constituents; the polyphenols, flavonoids and antioxidants at both $30{ }^{\circ} \mathrm{C}$ and $36{ }^{\circ} \mathrm{C}$. Studies on the sensory parameters, and the microbiological aspects of fermented fruit juices are needed to be carry out; specially to produce marketable products such as vinegar, with satisfactory organoleptic parameters, health benefits and shelf life.

\section{ACKNOWLEDGEMENT}

This work was financially supported by a grant from the National Research Council of Sri Lanka (NRC 16-025).

\section{AUTHOR CONTRIBUTION}

$\mathrm{AB}$ and ND carried out the experiment. BNP designed the research work, and both BNP and ND wrote the manuscript. 


\section{REFERENCES}

Akasaka N, Sakod, H, Hidese R, Ishii Y and Fujiwara S 2013 An efficient method using Gluconacetobacter europaeus to reduce an unfavorable flavor compound, acetoin, in rice vinegar production. Applied and environmental microbiology, 79 (23): 7334-7342. doi/10.1128/AEM.0239713

Amadi JA, Ihemeje A and Afam-Anene OC 2018 Nutrient and phytochemical composition of jackfruit (Artocarpus heterophyllus) pulp, seeds and leaves. International Journal of Innovative Food, Nutrition and Sustainable Agriculture, 6 (3): 27-32.

Bakir S, Toydemir G, Boyacioglu D, Beekwilder J and Capanoglu E 2016 Fruit antioxidants during vinegar processing: Changes in content and in vitro bio-accessibility. International journal of molecular sciences, 17 (10): 1658 . https://doi.org/10.3390/ ijms 17101658

Bello-Pérez L, García-Suárez FJ and AgamaAcevedo E 2007 Mango carbohydrates. Food, 1 (1), pp. 36-40.

Bouatenin KMJP, Kouame KA, Gueu-Kehi ME, Djeni, NDT and Dje KM 2021 Organic production of vinegar from mango and papaya. Food Science \& Nutrition, 9 (1): 190-196. https:// doi.org/10.1002/fsn3.1981

Brand-Williams W, Cuvelier ME and Berse CLWT 1995 Use of a free radical method to evaluate antioxidant activity. LWT-Food science and Technology, 28 (1): 25-30.

Budak NH, Ozçelik F and Güzel-Seydim ZB 2015 Antioxidant activity and phenolic content of apple cider. Turkish Journal of Agriculture-Food Science and Technology, 3 (6): 356360.

Chen H, Chen T, Giudici P and Chen F 2016 Vinegar functions on health: Constituents, sources, and formation mechanisms. Comprehensive Reviews in Food Science and Food Safety, 15 (6): 1124-1138. https:// doi.org/10.1111/1541-4337.12228
Chidi BS, Rossouw D, Buica AS and Bauer FF 2015 Determining the impact of industrial wine yeast strains on organic acid production under white and red wine-like fermentation conditions. South African Journal of Enology and Viticulture, 36 (3): 316327. https://doi.org/10.21548/ 36-3965

Chinese National Standard 2005 Edible Vinegar (CNS 14834, N5239). Ministry of Economic Affairs, Taiwan, Republic of China

Choo WS 2018 "Fruit pigment changes during ripening in reference module," in Food Science (Switzerland: Elsevier), 1-7.

Chun JE, Baik MY and Kim BY 2014 Manufacture and quality evaluation of purple sweet potato Makgeolli vinegar using a 2-stage fermentation. Food Science and Biotechnology, 23(4): 1145-1149.

Coelho E, Genisheva Z, Oliveira JM, Teixeira JA and Domingues L 2017 Vinegar production from fruit concentrates: Effect on volatile composition and antioxidant activity. Journal of food science and technology, 54(12):41124122. https://link.springer.com/ article/10.1007/s13197-017-2783-5

Compliance Policy Guide 1995 Center for Food Safety and Applied Nutrition Office of Regulatory Affairs, Food and Drug Administration

Ediriweera MK, Tennekoon KH, Samarakoon SR 2017 A review on ethnophamacological applications, pharmacological activities and bioactive compounds of mango (Mangifera indica L.). Evid.-Based Complementary Altern. Med. 2017, 24. doi: $10.1155 / 2017 / 6949835$

Ellong EN, Adenet S, Rochefort K 2015 Physicochemical, nutritional, organoleptic characteristics and food applications of four mangos (Mangifera indica L.) varieties. Food Nutr. Sci. 6, 242-253. doi: 10.4236/ fns.2015.62025

Gheflati A, Bashiri R, Ghadiri-Anari A, Reza JZ, Kord MT and Nadjarzadeh A 2019 
The effect of apple vinegar consumption on glycemic indices, blood pressure, oxidative stress, and homocysteine in patients with type 2 diabetes and dyslipidemia: A randomized controlled clinical trial. Clinical nutrition ESPEN, 33:132-138. https://doi.org/10.1016/ j.clnesp.2019.06.006

Gulçin I 2012 Antioxidant activity of food constituents: an overview. Archives of toxicology, 86 (3): 345-391. https:// link.springer.com/article/ $10.1007 \%$ 2Fs00204-011-0774-2

Gullo M, Caggia C, De Vero L and Giudici P 2006 Characterization of acetic acid bacteria in "traditional balsamic vinegar". International journal of food microbiology, 106 (2): 209-212. https://doi.org/10.1016/ j.ijfoodmicro.2005.06.024

Joint FAO/WHO Food Standards Programme 2000 Proposed Draft Revised Regional Standard for Vinegar. In: Codex Coordinating Committee for Europe

Joo KH, Cho MH, Park KJ, Jeong SW and Lim JH 2009 Effects of fermentation method and brown rice content on quality characteristics of brown rice vinegar. Korean Journal of Food Preservation, 16 (1): 33-39

Joshi VK and Sharma S 2009 Cider vinegar: Microbiology, technology and quality. In Vinegars of the World, 197-207, Springer, Milano. https:// link.springer.com/ chapter/10.1007/978-88-470-0866312

Kim SH, Cho HK and Shin HS 2012 Physicochemical properties and antioxidant activities of commercial vinegar drinks in Korea. Food Science and Biotechnology, 21 (6) : 17291734. 10.1007/s10068-012-0230-y

Konate M, Akpa EE, Bernadette GG, Koffi LB, Honore OG and Niamke SL, 2015 Banana vinegars production using thermotolerant Acetobacter pasteurianus isolated from Ivorian palm wine. Journal of Food Research, 4 (2), p. 92.
Larrauri JA, Ruperez P and Calixto FS 1996 Antioxidant activity of wine pomace. American Journal of Enology and Viticulture, 47 (4): 369-372

Li X, Chan LJ, Yu B, Curran P and Liu SQ 2012 Fermentation of three varieties of mango juices with a mixture of Saccharomyces cerevisiae and Williopsis saturnus var. mrakii. International Journal of Food Microbiology, 158(1):28-35. https:// doi.org/10.1016/ j.ijfoodmicro.2012.06.015

Lynch KM, Zannini E, Wilkinson S, Daenen L and Arendt EK 2019 Physiology of acetic acid bacteria and their role in vinegar and fermented beverages. Comprehensive Reviews in Food Science and Food Safety, 18(3):587625. https://doi.org/10.1111/15414337.12440

Maldonado-Celis ME, Yahia EM, Bedoya R, Landázuri $\mathrm{P}$, Loango $\mathrm{N}$, Aguillón $\mathrm{J}$, Restrepo B and Guerrero Ospina JC 2019 Chemical composition of mango (Mangifera indica L.) fruit: Nutritional and phytochemical compounds. Frontiers in plant science, 10, p.1073.

Mas A, Torija MJ, García-Parrilla MDC and Troncoso AM 2014 Acetic acid bacteria and the production and quality of wine vinegar. The Scientific World Journal. https:// doi.org/10.1155/2014/394671

Masibo $\mathrm{M}$ and $\mathrm{He}$ Q 2008 Major mango polyphenols and their potential significance to human health. Comprehensive reviews in food science and food safety, 7(4): 309-319.

Nanda K, Taniguchi M, Ujike S, Ishihara N, Mori H, Ono H and Murooka Y 2001 Characterization of acetic acid bacteria in traditional acetic acid fermentation of rice vinegar (komesu) and unpolished rice vinegar (kurosu) produced in Japan. Applied and Environmental Microbiology, 67 (2):986-990. https://doi.org/10.1128/ AEM.67.2.986-990.2001

Nelson DL, Cox MM 2017 "Lehninger," in Principles of biochemistry. Eds. Nelson DL, Cox MM (United States, 
NY: W. H. Freeman). doi: 10.1007/978-3-662-08289-8

Ordoudi SA, Mantzouridou F, Daftsiou E, Malo C, Hatzidimitriou E, Nenadis N and Tsimidou MZ 2014 Pomegranate juice functional constituents after alcoholic and acetic acid fermentation. Journal of functional foods, 8:161$168 . \quad$ http://dx.doi.org/10.1016/ j.jff.2014.03.015

Pure AE and Pure ME 2016 Antioxidant, antibacterial and color analysis of garlic fermented in kombucha and red grape vinegar. Applied Food Biotechnology, 3 (4), pp. 246- 252.

Quintana SE, Salas S and García-Zapateiro LA 2021 Bioactive compounds of mango (Mangifera indica): A review of extraction technologies and chemical constituents. Journal of the Science of Food and Agriculture, 101 (15): 6186-6192.

Ranasinghe RASN, Maduwanthi SDT and Marapana RAUJ 2019 Nutritional and health benefits of jackfruit (Artocarpus heterophyllus Lam.): A review. International journal of food science, 2019.

Saha P and Banerjee S 2013 Optimization of process parameters for vinegar production using banana fermentation. International Journal of Research in Engineering and Technology, 2 (9): 501-514.

Samad A, Azlan A and Ismail A 2016 Therapeutic effects of vinegar: a review. Current Opinion in Food Science, 8:56-61. https:// doi.org/10.1016/j.cofs.2016.03.001

Santos HO, de Moraes WM, da Silva GA, Prestes J and Schoenfeld BJ 2019 Vinegar (acetic acid) intake on glucose metabolism: A narrative review. Clinical nutrition ESPEN, 32:1-7. https:// doi.org/10.1016/j.clnesp.2019.05.008

Singleton VL, Orthofer R and LamuelaRaventós RM 1999 Analysis of total phenols and other oxidation substrates and antioxidants by means of folinciocalteu reagent. Methods in enzymology, 299, pp.152-178. https://
doi.org/10.1016/S0076-6879(99) 99017-1

Su MS and Chien PJ 2007 Antioxidant activity, anthocyanins, and phenolics of rabbiteye blueberry (Vaccinium ashei) fluid products as affected by fermentation. Food Chemistry, 104 (1):182-187. https://doi.org/10.3390/ ijms 17101658

Tesfaye W, Morales ML, Garcia-Parrilla MC and Troncoso AM 2002 Wine vinegar: technology, authenticity and quality evaluation. Trends in food science \& technology, 13(1):12-21. https:// doi.org/10.1016/S0924-2244(02) 00023-7

Torres-León C, Rojas R, Contreras-Esquivel JC, Serna-Cock L, Belmares-Cerda RE and Aguilar CN 2016 Mango seed: Functional and nutritional properties. Trends in Food Science \& Technology, 55: 109-117.

Chandrika UG, Jansz ER and Warnasuriya ND 2004 "Analysis of carotenoids in ripe jackfruit (Artocarpus heterophyllus) kernel and study of their bioconversion in rats," Journal of the Science of Food and Agriculture, (85) 2: 186-190.

Ubeda C, Callejon RM, Hidalgo C, Torija MJ, Troncoso AM and Morales ML, 2013 Employment of different processes for the production of strawberry vinegar: Effects on antioxidant activity, total phenols and monomeric anthocyanins. LWT-Food Science and Technology, 52 (2): 139-145. https:// doi.org/10.1016/j.lwt.2012.04.021

Vegas C, Mateo E, Gonzalez A, Jara C, Guillamon JM, Poblet M, Torija MJ and Mas A 2010 Population dynamics of acetic acid bacteria during traditional wine vinegar production. International Journal of Food Microbiology, 138(1-2):130-136. https://doi.org/10.1016/ j.ijfoodmicro.2010.01.006

Wu X, Yao H, Cao X, Liu Q, Cao L, Mu D, Luo $\mathrm{S}$, Zheng $Z$, Jiang $\mathrm{S}$ and $\mathrm{Li} \mathrm{X}$ 2017 Production of vinegar from purple sweet potato in a liquid fermentation process and investigation 
of its antioxidant activity. 3 Biotech, 7 (5):1-10. 10.1007/s13205-017-0939-7 Yunyang W 2005 Development of apple vinegar and its beverage. Science and Technology of Food Industry, 4

Zhishen J, Mengcheng $\mathrm{T}$ and Jianming W 1999 The determination of flavonoid contents in mulberry and their scavenging effects on superoxide radicals. Food chemistry, 64 (4): 555 559. 